\title{
Phytoplankton dynamic and bioindication in the Kondopoga Bay, Lake Onego (Northern Russia)
}

\author{
Sophia BARINOVA,,$^{*}$ Tatjana CHEKRYZHEVA ${ }^{2}$ \\ ${ }^{1}$ Institute of Evolution, University of Haifa, Mount Carmel, Haifa 3498838, Israel; ${ }^{2}$ Northern Water Problems Institute, Karelian Research \\ Centre, Russian Academy of Science, 50 Al. Nevskiy Pr., 185003, Petrozavodsk, Karelia, Russia \\ *Corresponding author: barinova@research.haifa.ac.il
}

\begin{abstract}
On the basis of our collected material and historical information we assess phytoplankton dynamics in Kondopoga Bay, the Lake Onego in 1993-2011. The summer communities from continuously studied sampling stations contain 100 species belonging to eight divisions: Bacillariophyta, 40; Chlorophyta, 25; Cyanobacteria, 13; Chrysophyta, 12; Euglenophyta, 2; Dinophyta, 4; Cryptophyta, 3; and Xanthophyta, 1. Sample richness varied between 16 and 54 species, with a negative overall trend during the study period, but increases in Cyanobacteria and Dinophyta. Bioindication analysis shows that water acidification slowly rising from 1993 to 2011 with organic pollution (Index saprobity S) and the number of species with heterotrophic ability. In 1990s, the total abundance and biomass were on average 1.5 times higher than in 2000-2011, having similar fluctuation ranges (Pearson 0.74), with peaks in 1996 and 2006. At the same time, species richness decreased, showing a depletion of algal communities. Two critically impacted periods are revealed with the Shannon index in 1996 and 2007 and on the basis of the Aquatic Ecosystem State Index (WESI) calculation in 1995 and 2007, related to Kondopoga industrial wastewater influx enriched in nutrients and other contaminants. As a whole, the WESI was extremely high, reflecting a high self-purification capacity in respect to phosphate concentration in the bay. The canonical corresponded analysis (CCA) shows two different sets of taxa, those stimulated by temperature and nitric nitrogen (Anabaena scheremetievii Elenkin, Dolichospermum lemmermannii (Ricter) P. Wacklin, L. Hoffmann \& J. Komárek, and Aulacoseira alpigena (Grunow) Krammer), and sensitive autotroph species inhabiting cool to temperate clear waters (Aulacoseira distans (Ehrenberg) Simonsen, Ankistrodesmus fusiformis Corda ex Korshikov, Mucidosphaerium pulchellum (H.C. Wood) C. Bock, Proschold \& Krienitz). The comparative statistics with GRAPS program revealed two cores of species richness in years 1996 and 2011 that included most of species. The long-term dynamics of relative cell volume shows that phytoplankton communities were enriched with small-celled species, such as Cyanobacteria (Microcystis aeruginosa (Kützing) Kützing) and Cryptophyta (Cryptomonas sp. and Katablepharis ovalis Skuja) in the period between 1998 and 2006. Pearson correlation for Shannon index and relative cell biovolume is negative (-0.79), showing high stability of species rich communities under environmental impacts. Two periods of dinoflagellate blooms $(1998,2007)$ followed the peaks of total abundance and biomass $(1996,2006)$. Such correlation makes the Kondopoga Bay ecosystem comparable to those of large lakes in spite of a heavier anthropogenic impact from Kondopoga pulp and paper mill wastewater.
\end{abstract}

Key words: phytoplankton, great lake, ecosystem, diversity, productivity, temporal dynamic.

Received: June 2013. Accepted: January 2014.

\section{INTRODUCTION}

The main characteristics of the North European region include the low range of altitudes and sharp seasonality of climate. The latitudinal distribution plays a major role in patterning plant species richness. Ecosystems of the large lakes in the region absorb the regional air and surface water pollution as well as enhancing the regional self-purification processes. Therefore, it is important to study the biotic responses to the long-term dynamics of environmental variables in the great northern lakes. Phytoplankton diversity of the Lake Ladoga (Petrova, 1968; Genkal and Trifonova, 2009; Petrova et al., 2010), the largest lake in the region, has received more attention in regional studies; the Lake Onego, next in the water area, is less studied though having a long history of research (Petrova, 1971, 1975, 1990; Vi- sljanskaya, 1990, 1999; Chekryzheva, 2008a, 2008b, 2012a, 2012b).

The Lake Ladoga rates as mesotrophic, whereas the Lake Onego is oligotrophic; correspondingly, its ecosystem is more sensitive to environmental impact. At this stage, we focused on phytoplankton diversity responses to environmental impacts in the most polluted Kondopoga Bay of the Lake Onego ecosystem that was formed under strong climatic as well as various anthropogenic impacts. In the process of natural eutrophication of the lake ecosystem structural adjustments and functional characteristics of phytoplankton are regulated mainly by two factors: temperature and nutrient concentration. Anthropogenic eutrophication of deep lakes like the Lake Onego affects nutrient concentration in the first place; the thermal 
regime remains essentially unchanged, except on account of seasonal fluctuations regulating algal growth in respect to the level of nutrient supply (Petrova, 1990). The fluctuations of the phytoplankton biomass show seasonal peaks in spring, autumn, and summer, associated with the main feature of the large lakes: the complexity of their thermal structure.

In order to reveal the long-term tendencies of the lake ecosystem development, we selected the summer season samples representing the most prominent peak of plankton biomass (Bilous et al., 2013) of the most anthropogenically impacted Kondopoga Bay. While the phytoplankton study of the Lake Onego has long story, the data on Kondopoga Bay have been never published. The aim of current research was ecological analysis of algal species preferences with help of bioindication and statistics during last twenty years. Methods used to reveal environmental impacts with the help of ecological indicators are the community structure fluctuation analysis, bio-indication of major impacting factors, calculations of integral density-diversity indices, and statistical approaches, linking structural and functional aspects of lacustrine communities with environmental fluctuations (Heywood, 2004).

\section{METHODS}

\section{Study area}

The Lake Onego is one of the largest and most northerly dimictic lakes in the world with the climatic defined thermal radiation mode and low biological productivity. The lake has an average depth of $30 \mathrm{~m}$ (maximum 120 $\mathrm{m}$ ), volume of water weight $291 \mathrm{~km}^{3}$, and the major water turnover period about 13.6 years. The lake water has a low mineral content (39-46 mg L $\mathrm{L}^{-1}$ ) and a low concentration of nutrients, the transparency of 4-5 m, and euphotic zone about 9-12 $\mathrm{m}$. The water quality is high, and its trophic status is oligotrophic, with phosphate load $0.10 \mathrm{~g} \mathrm{~m}^{2}$ per year (Filatov, 2010; Sabylina et al., 2012).

The Kondopoga Bay is located in the northwestern part of the Lake Onego in Northern Russia (Fig. 1), about $62^{\circ} 10^{\prime} \mathrm{N}, 34^{\circ} 18^{\prime} \mathrm{E}$. This area has a lowland landscape and represents a part of the large lake which is elevated by $33 \mathrm{~m}$ above sea level (asl). Soils are composed of sands, silt, peat, and pebble, overgrown with lichens and lichen-moss communities, which are replaced in the coastal area of the lake by sedges and grasses. Mean annual temperature measured by thermometer in parallel with sampling in August is less than $16^{\circ} \mathrm{C}$ (Sabylina, 1999). For 6-6.5 months, from December to May, the lake is covered with ice. In spring (May-June) and autumn (October) a thermocline is formed with an epilimnion thickness about $20 \mathrm{~m}$ (Kukharev and Lukin, 2008; Filatov, 2010). The studied part of the lake is mostly of thermokarst origin; the lake surface is about $223 \mathrm{~km}^{2}$, mean depth $10-50$ $\mathrm{m}$ and $110 \mathrm{~m}$ in the deepest part, fairly insulated from the main body of Lake Onego. It is periodically diluted by smelt waters during spring and autumn seasons. Sediments of the lake are diverse, varying from sand and gravel to peat. Water is slightly yellow or colorless with $\mathrm{pH}$ 6.5-7.5, and total dissolved solids about 39-46 $\mathrm{mg} \mathrm{L}^{-1}$. Aquatic macrophyte vegetation is developed along the shore line for over $1.26 \mathrm{~km}^{2}$ (up to $2 \%$ of littoral zone).

The water chemistry of the bay is governed by the inflow of the Suna River, as well as the industrial and municipal wastewater. For a long time, since 1929, the bay has been under the impact from the Kondopoga's pulp and paper mill wastewater and air pollution (Sabylina et al., 2012). Even with remediation of the bay waters, it is still subject to pollution and eutrophication impacts (Timakova et al., 2011; Sabylina et al., 2012). The bay is narrow, and an intermittent circulation of water masses due to wind currents, especially in the summer, provides for removal of sporadic pollution substances from the Kondopoga Bay to the pelagic area of the lake (Boyarinov and Rudnev, 1990). Water flow stirred by winds promotes removal of waste water (with north-west winds), or their

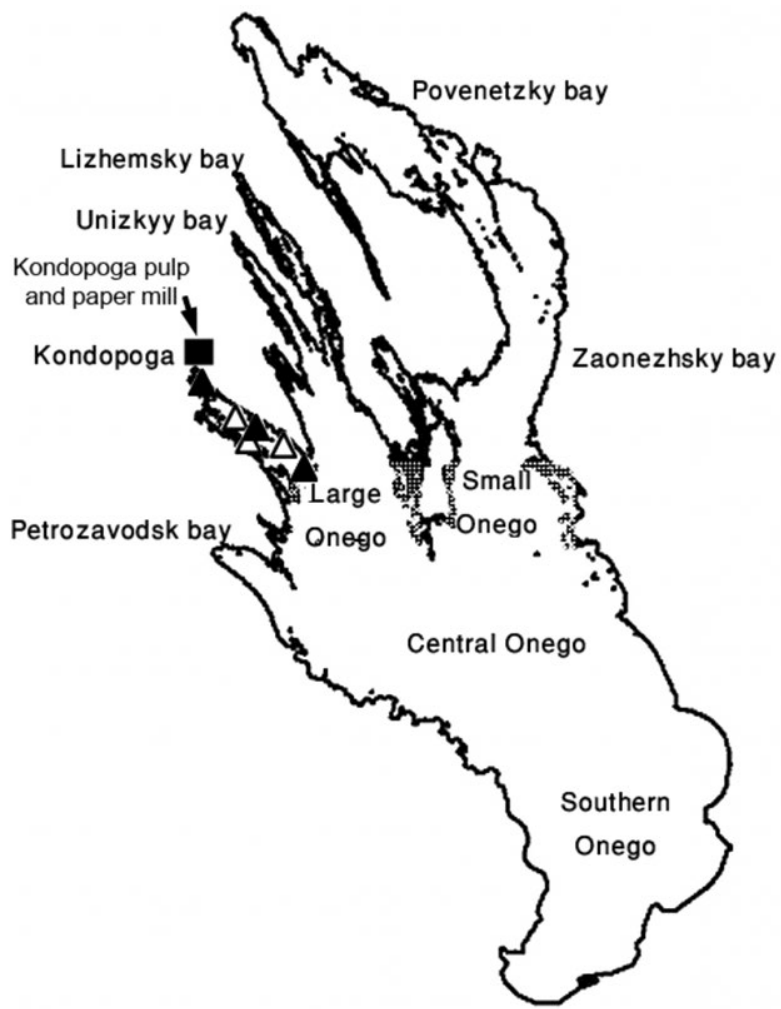

Fig. 1. Location of the studied site in the Kondopoga Bay of the Lake Onego with sampling points as white (sporadically) and black (continuously) triangles. Black rectangles are sampling stations with continuous monitoring during 1993-2011. 
blocking (with south-east winds). Thus, with blocking of sewage in the apical part of the bay, as well as in calm weather, the concentration of certain chemicals in the narrow north-western part of the bay is higher than in the middle and the widest south-eastern parts of it (Sabylina and Ryzhakov, 2007).

\section{Sampling and laboratory studies}

We used the previously collected material (1999, $2005-2008,2011)$ and historical data provided by the Northern Water Problems Institute, Karelian Research Centre, Russian Academy of Science (1993-1998) on abundance and biomass of summer phytoplankton of the Kondopoga bay from three major sampling stations (black triangles) with continuous monitoring (Fig. 1). Water samples for chemistry and phytoplankton analyses $(1 \mathrm{~L})$ were collected in parallel with sampling from the same stations (Fig. 1) in the epilimnion, $0.5 \mathrm{~m}$ below the water surface of the pelagic zone in July-August, 19932011. Samples were taken with a bathometer, filtered with membrane filters of $0.95-1.02 \mu \mathrm{m}$ and fixed with $3 \%$ lugol-formaldehyde fixator solution. Species definition and counting were performed in the Nageotte chamber of $0.02 \mathrm{~mL}$. The biovolume of each species was calculated on the basis of the geometric cell volumes (Morduhay-Boltovskiy, 1975; Fedorov, 1979). Nutrients concentration data (Pmin, Ptot, N-NH ${ }_{4}, \mathrm{~N}^{-} \mathrm{NO}_{2}, \mathrm{~N}_{-} \mathrm{NO}_{3}$, Norg, Ntot, Si, Fetot), were taken from the database of The Laboratory of Hydrochemistry and Hydrobiology of Northern Water Problems Institute (Sabylina, 1999; Sabylina and Ryzhakov, 2007; Sabylina et al., 2010). For taxonomic identification, a series of monographic studies have been used (Zabelina et al., 1951; Hollerbach et al., 1953; Kiselev, 1954; Matvienko, 1954; Popova, 1955; Dedusenko-Schegoleva et al., 1959; DedusenkoSchegoleva and Hollerbach, 1962; Palamar-Mordvintseva, 1982; Korshikov, 1953; Kosinskaya, 1960; Matviyenko and Litvinenko, 1977; Starmach, 1985; Komárek and Anagnostidis, 1986; Anagnostidis and Komárek, 1988; Krammer and Lange-Bertalot, 1986, 1988, 1991a, 1991b).

\section{Bio-indication and indices calculation}

Our ecological analysis has revealed a grouping of freshwater algae indicators in respect to $\mathrm{pH}$, salinity and saprobity and the other habitat conditions (Barinova et al., 2006). Each group was separately assessed for its bio-indication significance. The species that predictably responded to environmental variables can be used as bio-indicators of the aquatic ecosystem's response to eutrophication, $\mathrm{pH}$ levels (acidifications), salinity, and organic pollutants. Saprobic Index (S) was calculated after Sládeček $(1973,1986)$ for the algal community on the basis of the species-specific saprobity level (Barinova et al., 2006) and the relative abundance of each species in the community as:

$$
\mathrm{S}=\sum_{i=1}^{n}\left(\mathrm{~s}_{i} \cdot \mathrm{a}_{i}\right) / \sum_{i=1}^{n}\left(\mathrm{a}_{i}\right)
$$

where: $\mathrm{S}$ is the Saprobity Index of algal community; $\mathrm{s}_{i}$ is the species-specific saprobity index; $\mathrm{a}_{i}$ is the species abundance.

The Saprobic Index S indicates the saprobic zone and has been adapted for classes of water quality based on the ecological classification widely used in European and Asian countries (Barinova et al., 2006; Romanenko et al., 1990; Whitton et al., 1991; European Commission, 2000).

The calculated integral index of aquatic ecosystem sustainability (Aquatic Ecosystem State Index, WESI) is based on the water-quality classes (Barinova et al., 2006, 2010a,b; Barinova, 2011; Barinova and Krassilov, 2012; Barinova and Sivaci, 2013) reflecting self-purification capacities for each of the sampling stations. If WESI is equal to or larger than 1, the photosynthetic level is positively correlated with the level of nitrate concentration. The WESI is less than 1 attests to photosynthesis being suppressed, presumably owing to a toxic, light intensity or other disturbance (Barinova, 2011; Barinova et al., 2006, 2010b; Saks et al., 1976).

For environmental variables, we applied the 5-Class System adapted to water-quality evaluation based on more than 30 parameters (Sladecek, 1973; Barinova et al., 2006).

The Shannon's diversity index (Odum, 1969) was calculated as:

$\bar{H}=-\sum_{i=1}^{s} \frac{n_{i}}{N} \log _{2} \frac{n_{i}}{N}$

where: $N$ is the total cells (individuals) number, $1 ; s$ is the species number; $n_{i}$ is the individuals number of every species; $\bar{H}$ is the Shannon diversity index. The mean phytoplankton community cell size was estimated from the ratio between total biovolume and total abundance (according to Pugnetti et al., 2004). Statistical methods of comparative floristic analysis (Novakovsky, 2004) were used for calculating similarity of algal communities in the sampling stations.

\section{Statistical analysis}

Structural diversity was calculated using statistical methods recommended by Heywood (2004) for floristic and taxonomic studies. At the same time, the statistical significance of variables was assessed using Pearson correlation method. Statistical analysis of relationships between species diversity of algal communities and their environmental variables were studied by canonical correspondence analysis (CCA) with CANOCO for Windows 4.5 package (Ter Braak and Šmilauer, 2002). 
Statistical significance of each variable was assessed using the Monte Carlo unrestricted permutation test involving 999 permutations (Ter Braak, 1990). Variables of greatest correlation values have been included in analysis. For CCA analysis we choose species with abundance values from $4 \%$ to $25 \%$ (maximal).

\section{RESULTS}

\section{Species richness and bio-indication}

In the bathometric phytoplankton of the Kondopoga Bay of Lake Onego in the summer period, there are 100 taxa below the rank of genus, belonging to eight divisions: Bacillariophyta, 40; Chlorophyta, 25; Cyanobacteria, 13; Chrysophyta, 12; Euglenophyta, 2; Dinophyta, 4; Cryptophyta, 3; and Xanthophyta, 1 (Tab. 1). With large for oligotrophic lakes species richness, phytoplankton was dominated by diatoms in all seasons of the year. The most abundant of them are the cool temperate species of spring and autumn communities (Aulacoseira islandica, A. italica var. italica, and A. alpigena), as well as the summer temperate species (Tabellaria fenestrata, Asterionella formosa, and Fragilaria crotonensis).

Species richness in the summer planktonic communities varied between 54 in 1993 and 16 in 2007 and had a negative linear trend $\left(\mathrm{R}^{2}=0.69\right)$ during the study period, with increases in Cyanobacteria and flagellate species, such as dinophytes (Tab. 1; Figs. 2a; 3b). Bio-indication analysis on the basis of the species list (Tab. 1) suggests that water acidification is slowly increasing during the study period with removal of alkalibiontes from the communities (Fig. 2b). Organic pollution slightly increased with winnowing of saproxenes (Fig. 2c) and the rise of diatom species with ability to heterotrophic type of nutrition in unfavorable environment (Saks et al., 1976) such as Nitzschia acicularis
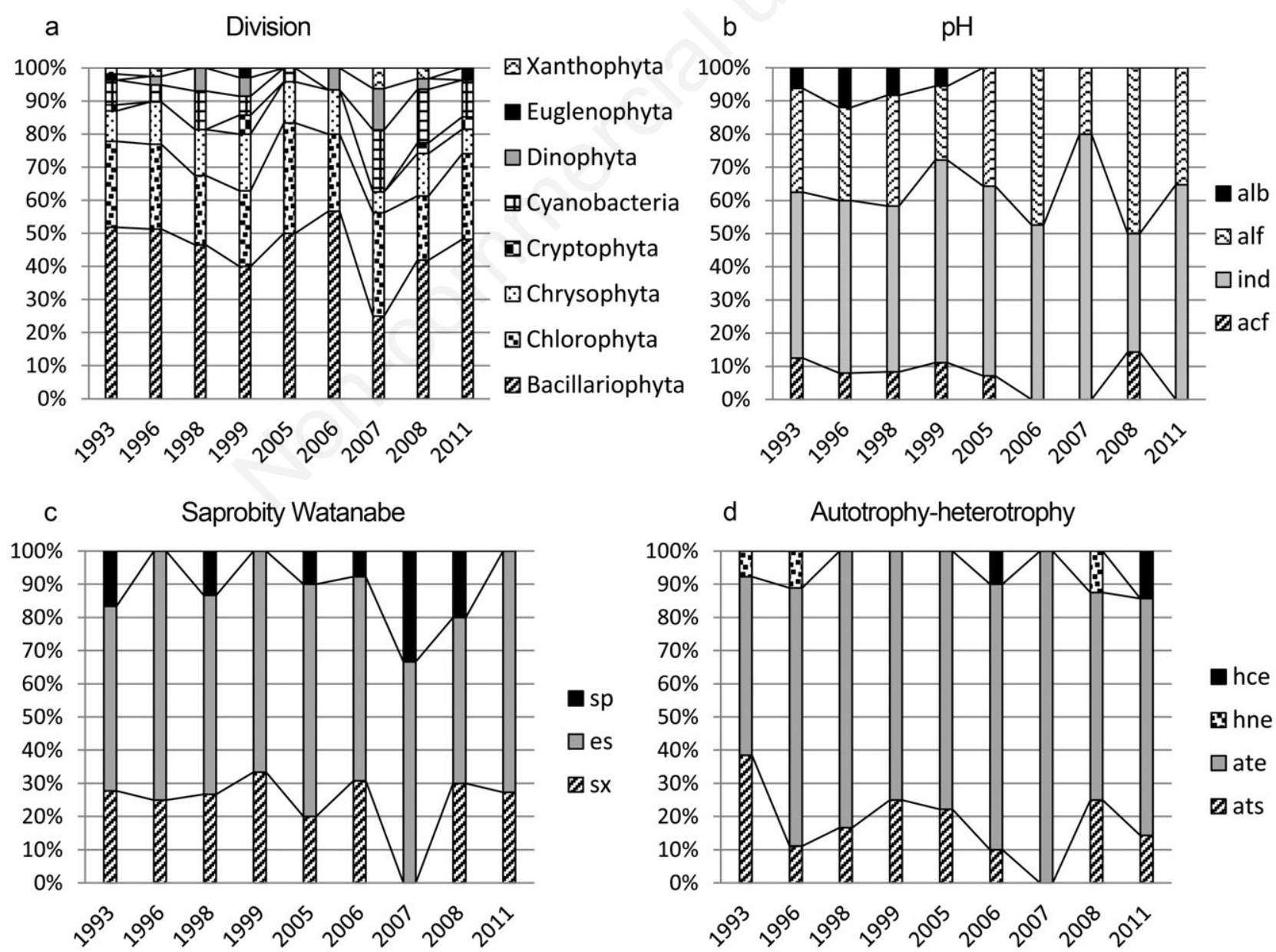

Fig. 2. Dynamics (1993-2011) of phytoplankton divisional species richness (a), bio-indication of pH (b), organic pollution (c), and nutrition type (d) in the Kondopoga Bay of the Lake Onego. Abbreviation of ecological groups are given in Tab. 1. 
and Cyclotella meneghiniana (Van Dam et al., 1994) in the last year's communities (Fig. 2d).

\section{Chemical and phytoplankton variables}

Chemical variables concentrations, in particular the phosphates (Pmin) in the bay water (Tab. 2) are increased during the study period and correspond to transition from oligotrophic (0 to $\left.7.6 \mathrm{mkg} \mathrm{P} \mathrm{L}^{-1}\right)$ to a mesotrophic (18.7 mkg $\mathrm{P} \mathrm{L}^{-1}$ ) state of the lake ecosystem (Carlson and Simpson, 1996). Tab. 2 shows increasing in water temperature during study period. It can be seen that in 2005-2011 the water temperature in the bay was on average $\left(17.1^{\circ} \mathrm{C}\right)$ higher than the long-term averages $\left(16.8^{\circ} \mathrm{C}\right)$, and also, on average, higher than in the $1990 \mathrm{~s}\left(16.3^{\circ} \mathrm{C}\right)$. As can be seen in Tab. 3, mean value of abundance and biomass were rather low, fluctuating between $177-5858$ cells per liter in 2007 and 2006, respectively, and $0.336-5.872 \mathrm{mg} \mathrm{L}^{-1}$ in 2011 and 1996, respectively, which correspond to oligotrophic state of the Kondopoga Bay. The major productive elements as phosphates and nitrates were not so high in the studied site and corresponded to the of water quality Class I-II according to Sládeček’s, (1973) classification (Barinova et al., 2006). Fig. 3 shows that diatoms were most abundant in the bay communities over the studied period with fluctuation of their abundance and biomass. Only in 1998 and 2007 this group contained less than 50\% of total cell numbers. During 1996-2005 and 2008-2011, the planktonic communities were enriched by abundant Chlorophyta, with a peak of abundance in 2005. The planktonic Cyanobacteria species actively developed with the rises of cell abundance in 1993, 1998, and 2007, whereas the Dinophyta bloomed in summer period of 1998 . The tendency of ecosystem diversity fluctuation shows an increase of phytoplankton abundance and biomass in 2004 to 2011, approaching the the values for 1993, the starting year of our analysis. In the biomass fluctuation we can see that diatoms also represent more than $50 \%$ of the total, excluding 1998 and 2007. Two periods can be revealed: 1998-2006 and 2007-2011 in which communities were dominated by dinoflagellates and green algae, resulting in the reduction of diatoms.

Total abundance and biomass fluctuated (Fig. 4a) with similar tendencies over the studied period showing peaks in 1996 and 2006. Pearson correlation index is 0.74 with $\mathrm{P}$ value of 0.006 . Species richness decreased during the studied period from 54 to 21 species with a minimum of 16 species in 2007 (Fig. 4b), a considerable depletion of algal communities. But structural parameters such as the Shannon index show only a periodical impact on phytoplankton community, with lower values in 1996 and 2007 coinciding with the peaks of cell abundance values. Species richness and Shannon index show conformable fluctuation in 1993-1998 and 2006-2011, but opposite sign fluctuations in 1999-2005. Both assessments revealed two years in which the Kondopoga Bay phytoplankton communities were impacted with the input of wastewater rich in nutrients and other contaminants that came from the Kondopoga industry works.

\section{Indices calculation}

The Aquatic Ecosystem State Index WESI calculated on the basis of the Saprobity index S and concentration of major productive variables, nitrates and phosphates (Fig. 5) shows high amplitude fluctuation during the study a

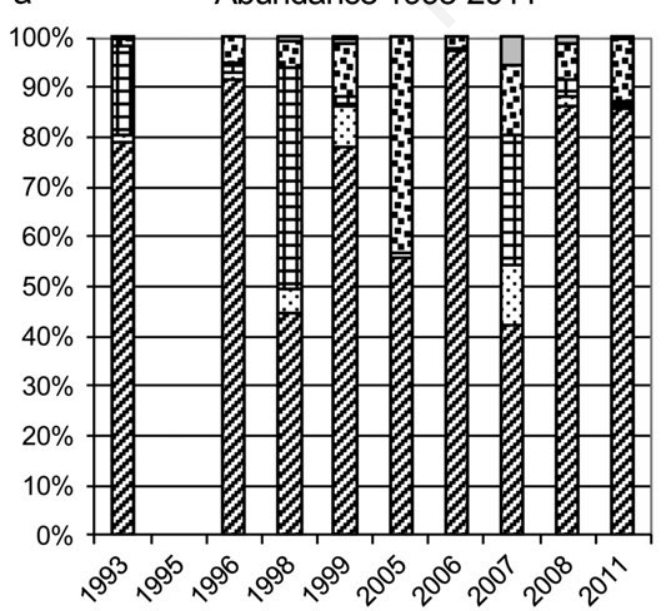

-Euglenophyta $\square$ Dinophyta 巴Chlorophyta 由Cyanobacteria ๑Chrysophyta $\boldsymbol{\Delta}$ Bacillariophyta

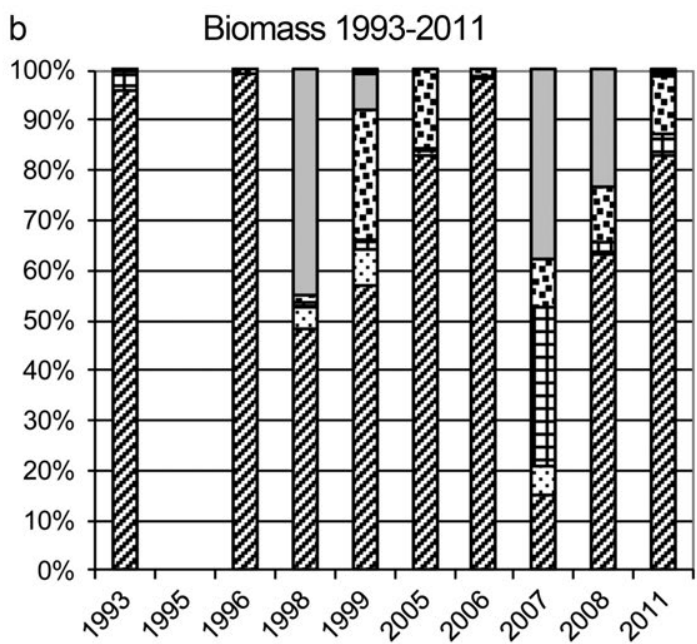

Fig. 3. Dynamics (1993-2011) of phytoplankton abundance and biomass over taxonomic Divisions in the Kondopoga Bay of the Lake Onego. 


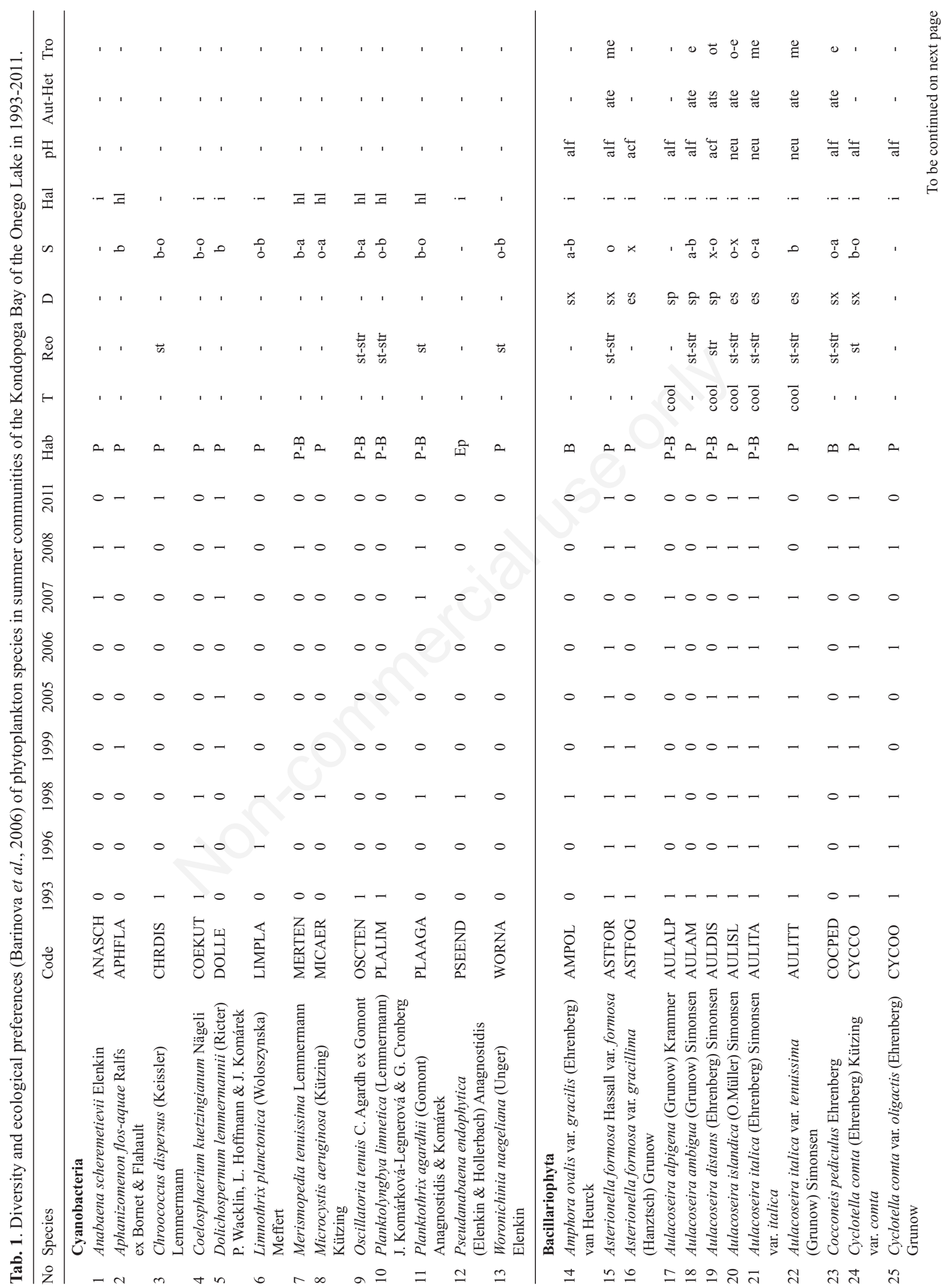




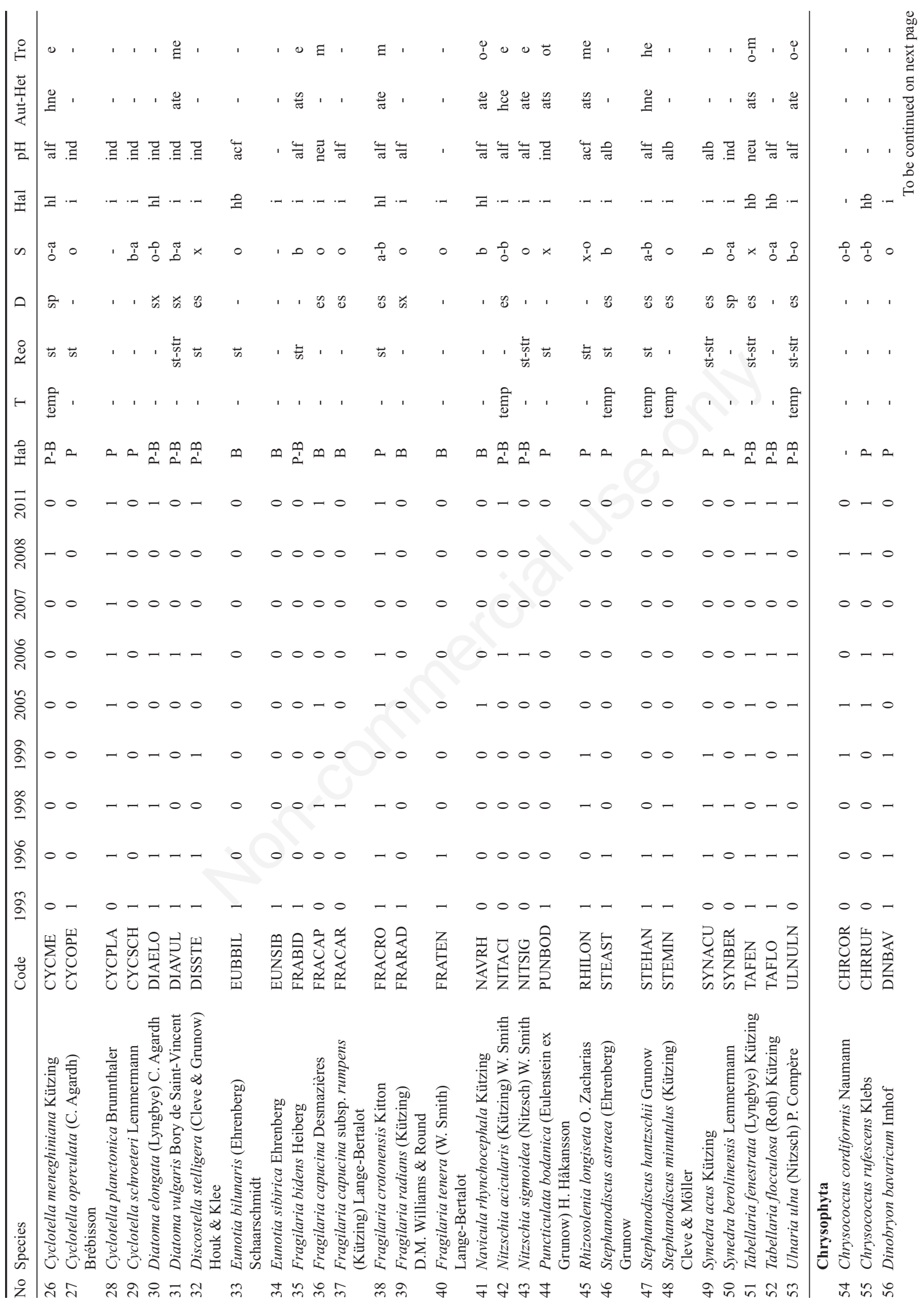



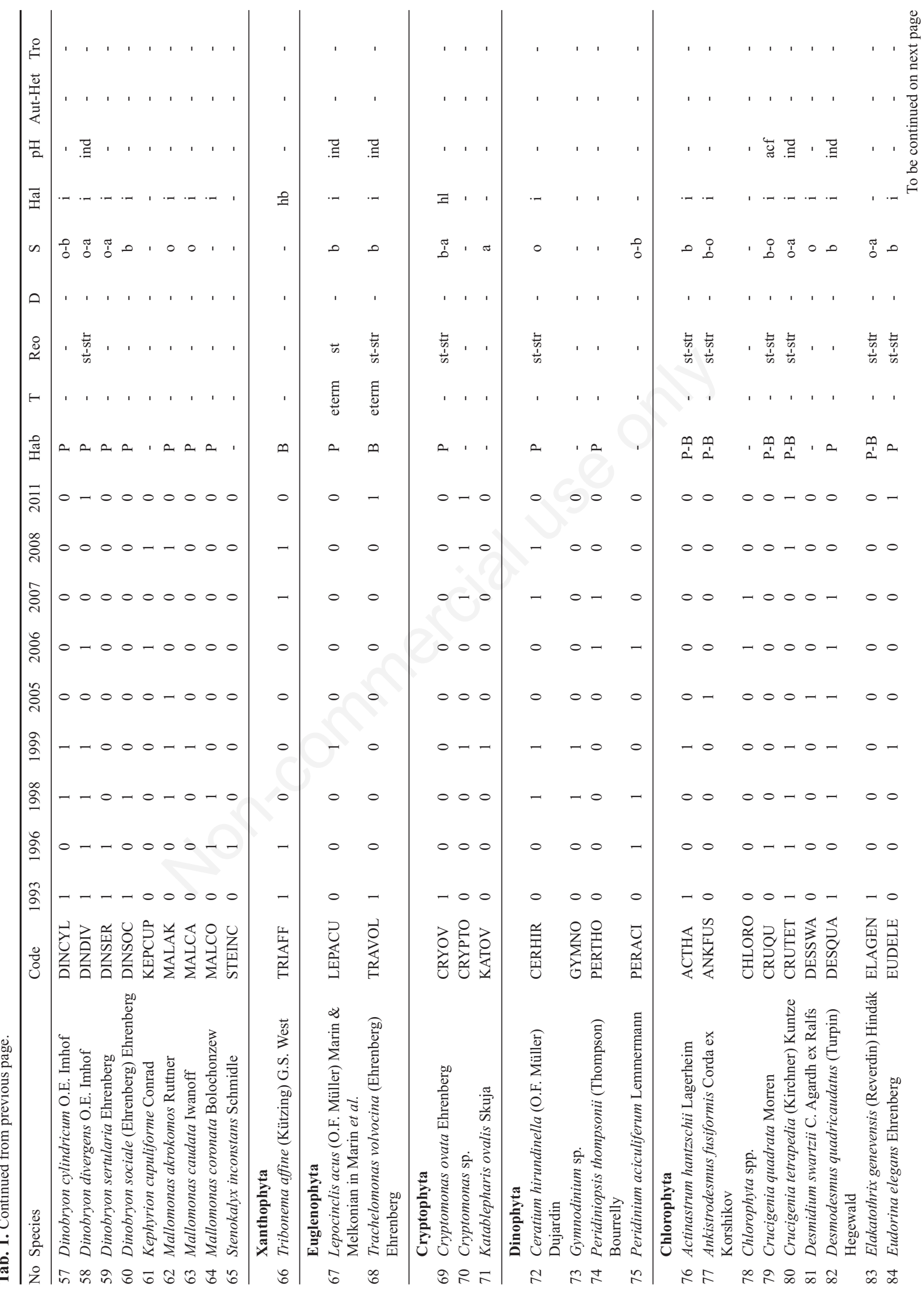


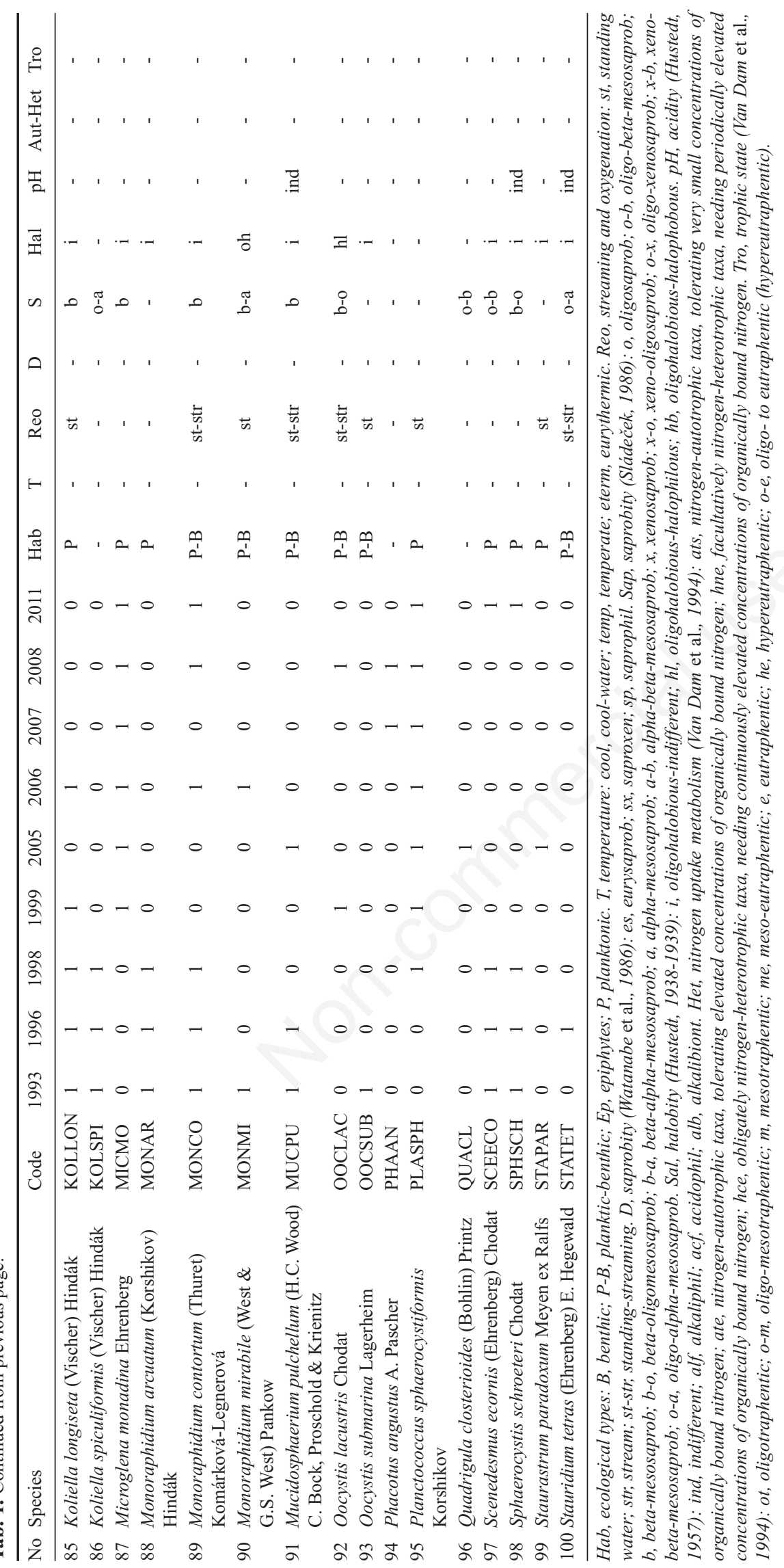


period. Even in the most polluted Kondopoga Bay, the WESI remained above normal $(=1)$, attesting to an extremely high self-purification capacity during the entire study period. The value of index calculated on the basis of phosphate concentration is larger than for the nitrate index, which can be related to a lower concentration of the usable for photosynthesis phosphates than nitrates. However, two critical periods in 1995 and 2007 can be seen in Fig. 5, with WESI lows in both phosphates and nitrates.

\section{Species-environment relationships}

Calculation of regression coefficients in CCA shows significant positive relationships between species richness and Norg (0.697), and negative relationships of Saprobity Index S and water temperature (-0.667), ammonia (-0.694), and silica $(-0.725)$. In turn, the chemical variables are dependent on each other as nitric nitrogen concentration and temperature (0.707), or nitric nitrogen and Norg (-0.725), as well as iron and temperature (0.904). For accomplishing CCA analysis we choose 18 abundant species and five chemical variables $\left(\mathrm{N}-\mathrm{NO}_{3}, \mathrm{~T}, \mathrm{~N}-\mathrm{NH}_{4}, \mathrm{Si}\right.$, and Norg). Planktonic community response to environmental impact (Fig. 6) reveals two different sets of environmental variables; the first includes temperature and nitric nitrogen, the second
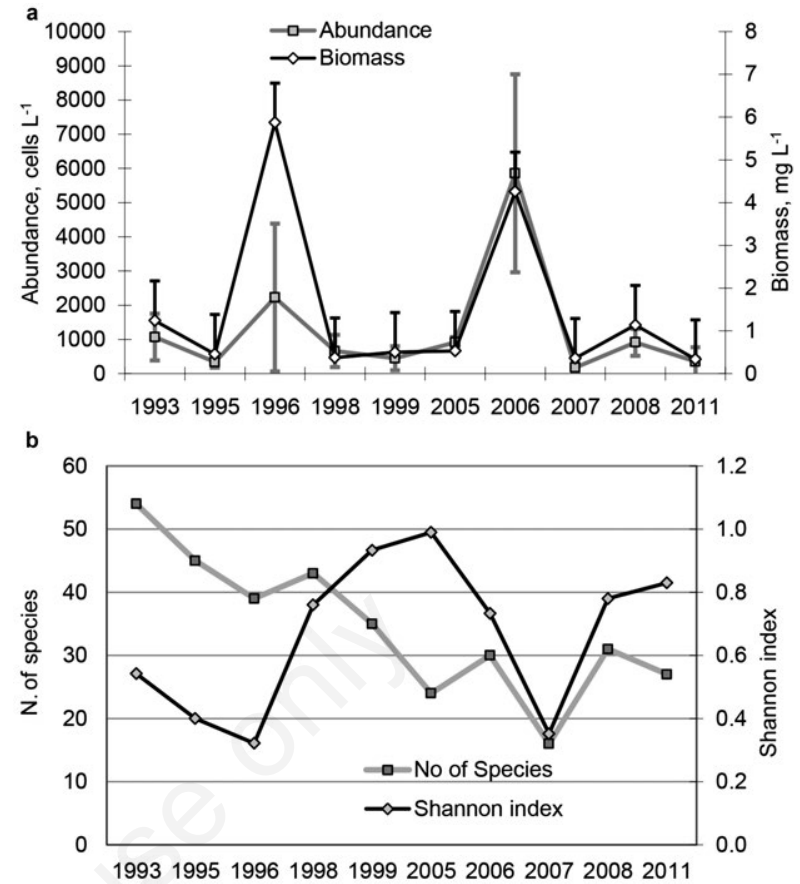

Fig. 4. Dynamics (1993-2011) (with standard deviation) of phytoplankton abundance and biomass (a), species richness and Shannon index (b), in the Kondopoga bay of the Lake Onego.

Tab. 2. Mean values of environmental variables $\left(\mathrm{mg} \mathrm{L}^{-1}\right)$ in the Kondopoga Bay of the Onego Lake.

\begin{tabular}{|c|c|c|c|c|c|c|c|c|c|c|c|}
\hline Year & $\mathrm{T}\left({ }^{\circ} \mathrm{C}\right)$ & Pmin & TSS & Ptot & $\mathrm{N}-\mathrm{NH}_{4}$ & $\mathrm{~N}-\mathrm{NO}_{2}$ & $\mathrm{~N}-\mathrm{NO}_{3}$ & Norg & Ntot & $\mathrm{Si}$ & Fetot \\
\hline 1993 & 15.6 & 0.0013 & 0.009 & 0.03 & 0.05 & 0.002 & 0.12 & 0.52 & 0.73 & 0.33 & 0.05 \\
\hline 1996 & 15.6 & 0.0030 & 0.014 & 0.04 & 0.05 & 0.001 & 0.07 & 0.55 & 0.68 & 0.36 & 0.09 \\
\hline 1998 & 18.2 & 0.0013 & 0.008 & 0.02 & 0.06 & 0.002 & 0.14 & 0.48 & 0.69 & 0.53 & 0.18 \\
\hline 1999 & 16.0 & 0.0027 & 0.000 & 0.03 & 0.05 & 0.001 & 0.11 & 0.42 & 0.59 & 0.22 & 0.11 \\
\hline 2005 & 17.2 & 0.0000 & 0.000 & 0.02 & 0.04 & 0.002 & 0.24 & 0.17 & 0.45 & 0.35 & 0.14 \\
\hline 2006 & 16.0 & 0.0001 & 0.000 & 0.02 & 0.03 & 0.001 & 0.17 & 0.41 & 0.61 & 0.06 & 0.10 \\
\hline 2007 & 19.9 & 0.0062 & 0.000 & 0.04 & 0.04 & 0.000 & 0.27 & 0.33 & 0.65 & 0.66 & 0.18 \\
\hline 2008 & 16.6 & 0.0076 & 0.000 & 0.03 & 0.05 & 0.002 & 0.12 & 0.31 & 0.48 & 0.68 & 0.10 \\
\hline 2011 & 16.0 & 0.0187 & 0.000 & 0.04 & 0.06 & 0.000 & 0.09 & 0.49 & 0.65 & 0.60 & 0.10 \\
\hline
\end{tabular}

Pmin, mineral phosphorous; TSS, total suspended solids; Ptot, total phosphorous; Norg, organic nitrogen; Ntot, total nitrogen; Si, silica; Fetot, total iron.

Tab. 3. Dynamics of mean biological variables of phytoplankton assemblages in the Kondopoga Bay of the Onego Lake.

\begin{tabular}{|c|c|c|c|c|c|c|}
\hline Year & N. of species & Shannon index & Index $\mathrm{S}$ & Abundance, cells L ${ }^{-1}$ & Biomass, $\mathrm{mg} \mathrm{L}^{-1}$ & $\begin{array}{l}\text { Relative cell volume, } \\
\mathrm{mg} \mathrm{cells}^{-1}\end{array}$ \\
\hline 1993 & 54 & 0.542 & 1.752 & 1070.9 & 1.242 & 0.0012 \\
\hline 1995 & 45 & 0.400 & 1.703 & 340.0 & 0.458 & 0.0013 \\
\hline 1996 & 39 & 0.322 & 1.840 & 2227.7 & 5.872 & 0.0026 \\
\hline 1998 & 43 & 0.760 & 1.563 & 662.0 & 0.375 & 0.0006 \\
\hline 1999 & 35 & 0.933 & 1.773 & 449.0 & 0.504 & 0.0011 \\
\hline 2005 & 24 & 0.990 & 1.830 & 915.0 & 0.531 & 0.0006 \\
\hline 2006 & 30 & 0.733 & 1.940 & 5858.6 & 4.258 & 0.0007 \\
\hline 2007 & 16 & 0.352 & 1.625 & 177.5 & 0.364 & 0.0020 \\
\hline 2008 & 31 & 0.780 & 1.717 & 916.0 & 1.137 & 0.0012 \\
\hline 2011 & 27 & 0.830 & 1.720 & 355.0 & 0.336 & 0.0009 \\
\hline
\end{tabular}


Norg, and N-NH 4 . The first set variables are manifest in the abundance of the temperature and nitrogen indicators Anabaena scheremetievii and Dolichospermum lemmermannii (Cyanobacteria), and Aulacoseira alpigena from diatoms (marked in the upper right circle). The second set variables are relevant to species sensitive to ammonia and Norg, marked in the upper left circle, in particular the diatoms Aulacoseira distans (cool oligotrophic water, xenooligosaprobiont) and greens Ankistrodesmus fusiformis (beta-oligosaprobiont) and Mucidosphaerium pulchellum (beta-mesosaprobiont) which are known as autotrophic species inhabiting cool to temperate clear waters (Tab. 1; Barinova et al., 2006).

\section{Comparative statistics}

With the help of the GRAPHS Program, a statistical comparison of species richness revealed that all algal diversity of the studied years can be divided into three major clusters with a similarity level of 50\% (Fig. 7). The first cluster of similarity tree includes species sampled in 1993, 1996, and 1998; the second in 1999, 2005, 2006, and 2011, and the third in 2007 and 2008. The calculation of species overlap shows a high level of similarity of sampling year phytoplankton, with fluctuation between $46 \%$ and $64 \%$. The dendrite reveals two cores of species richness, in years 1996 and 2011, respectively.

\section{DISCUSSION}

The analysis of long time series of air and water temperature at various lakes of the world showed recent warming trends (Ministry of the Environment and Statistics, 2010; George, 2010; Nazarova, 2012). This can lead to transformation of distribution and increase in phytoplankton productivity (Jeppesen et al., 2009). In the Kondopoga Bay, mean phosphates concentration remain low (Tab. 2) with increasing tendency that correspond to transition from oligotrophic ( 0 to $7.6 \mathrm{mkg} \mathrm{P} \mathrm{L}^{-1}$ ) in 1993-2008 to a mesotrophic $\left(18.7 \mathrm{mkg} \mathrm{P} \mathrm{L}^{-1}\right)$ state in 2011 of the lake ecosystem (Carlson and Simpson, 1996) in controversy to Sabylina et al. (2012) conclusion about of the oligotrophic state over all studied periods. In the same time, significant changes were detected in the total nitrogen, including the perennial concentration of its mineral forms consumed by phytoplankton for the entire study period.

The total taxonomic diversity for all sampling stations in the open water period comprises 228 taxa below the rank of genus, belonging to eight divisions: Bacillariophyta, 97 (43\%); Chlorophyta, 57 (25\%); Cyanobacteria, 17 (7\%); Chrysophyta, 29 (13\%); Euglenophyta, 12 (5\%); Dinophyta, 6 (3\%); Cryptophyta, 7 (3\%); Xanthophyta, 3 (1\%); (Chekryzheva, 2008). The most representatives diversity and abundance data are obtained for three major monitoring stations where we have continuous counting results for the entire period (Tab. 1, Fig. 1). The divisional distribution is like in the total flora, with slight increase in Cyanobacteria.

The cryptophyta algae are observed in plankton of the bay since the mid-1990s, with maximal concentration in the apical north-western part of the bay in August 1999.

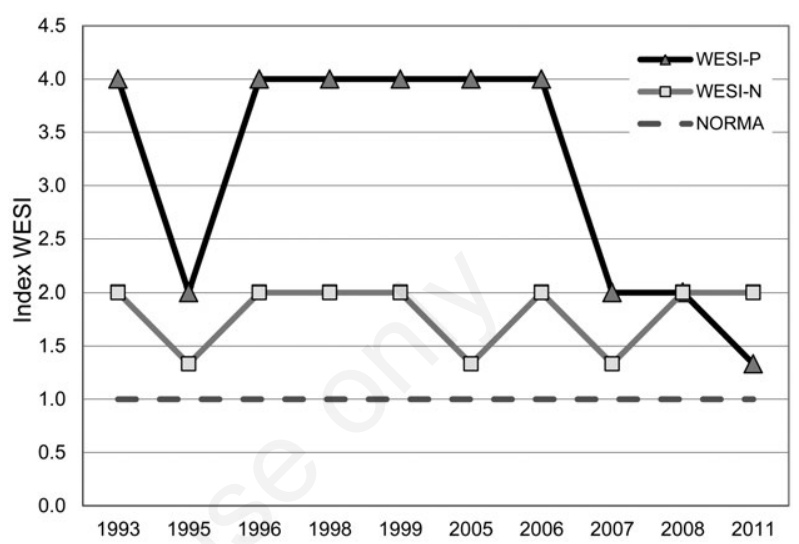

Fig. 5. Dynamics (1993-2011) of the aquatic ecosystem state index WESI calculated on the basis of the Saprobity index $\mathrm{S}$ and concentration of $\mathrm{N}-\mathrm{NO}_{3}$ and $\mathrm{P}-\mathrm{PO}_{4}$ in the Kondopoga Bay of the Lake Onego. Index WESI=1 marked as NORMA.

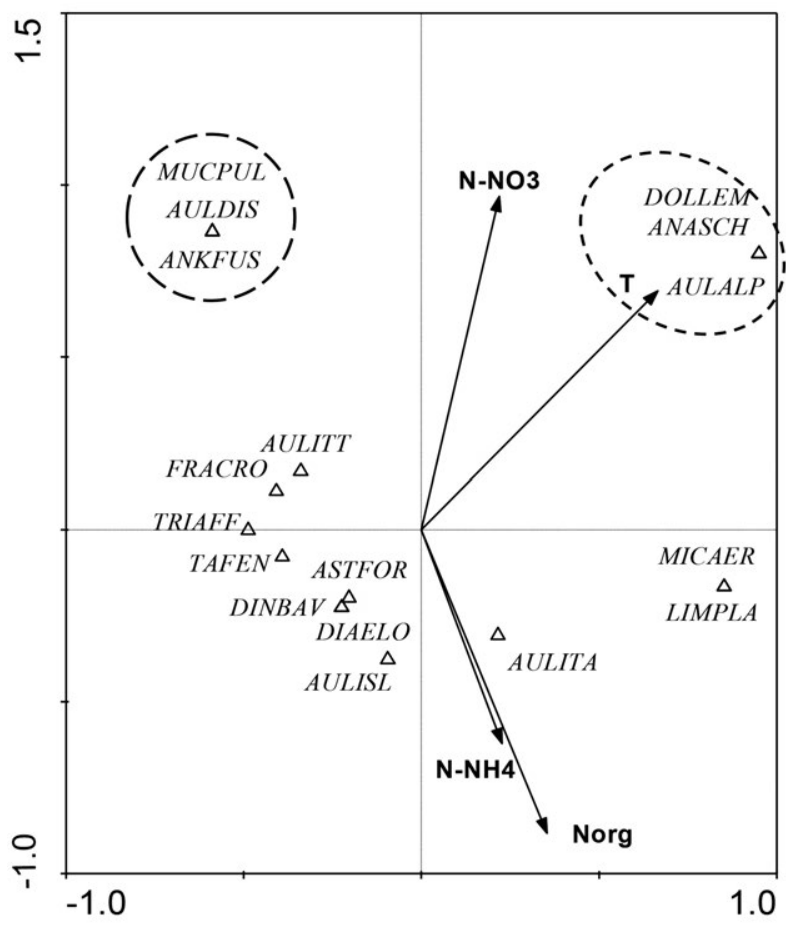

Fig. 6. Biplot of canonical corresponded analysis (CCA) for phytoplankton communities and environmental variables in the Kondopoga Bay of the Lake Onego. Abbreviated species names are given in Tab. 1. Monte Carlo test: eigenvalue $=0.804, \mathrm{P}=0.05$. 
As in the other large regional lakes, the ratios of species numbers of taxonomic divisions have not changed significantly in the process of anthropogenic eutrophication. At the same time, a characteristic feature of eutrophication is an increase in blue-green algae and green chlorococcalean (Tab. 1) in abundance and biomass (Tab. 3). Cryptophyta algae exhibit ecological features such as a high growth rate, mobility, ability to mixotrophic nutrition as well as osmo- and fagotrophy (Stewart and Wetzel, 1986; Olrik, 1998). Cyanobacteria that display adaptability to high concentrations of organic nitrogen and ammonia are joined by cryptophytes in showing the ability of heterotrophic nutrition (Trifonova, 1990; Blomqvist et al., 1994; Rücker et al., 1997; Havens et al., 1998). Lately, the increasing role of diatoms in phytoplankton communities is accompanied by the increasing ability of heterotroph nutrition (Van Dam et al., 1994) in this group also (Figs. 3 and 4a). Together with heterotrophic Cyanobacteria such as Oscillatoria members (Trifonova, 1990) they contribute to the number of indicator species for organic pollution (Fig. 2 a-d). In calm weather algal blooms caused by the massive development of blue-green algae such as Oscillatoria tenuis, Anabaena scheremetievii, Woronichinia naegeliana, as well as green algae, Eudorina elegans, Sphaerocystis schroeteri and Mucidosphaerium pulchellum, were observed. It means that a number of diatom species is replaced by green algae and cyanobacteria, well adapted to temperate waters. Diatoms, such as Aulacoseira, have an adaptive optimum in low-temperature ranges (Barinova et al., 2006: 12 taxa are low temperature indicators from 15 taxa of Aulacoseira with known temperature preferences). Therefore, it can be concluded that at temperature and organic pollution are the major factors of the diversity forming process in planktonic communities of the Kondopoga Bay.

A quantitative comparison of phytoplankton in the

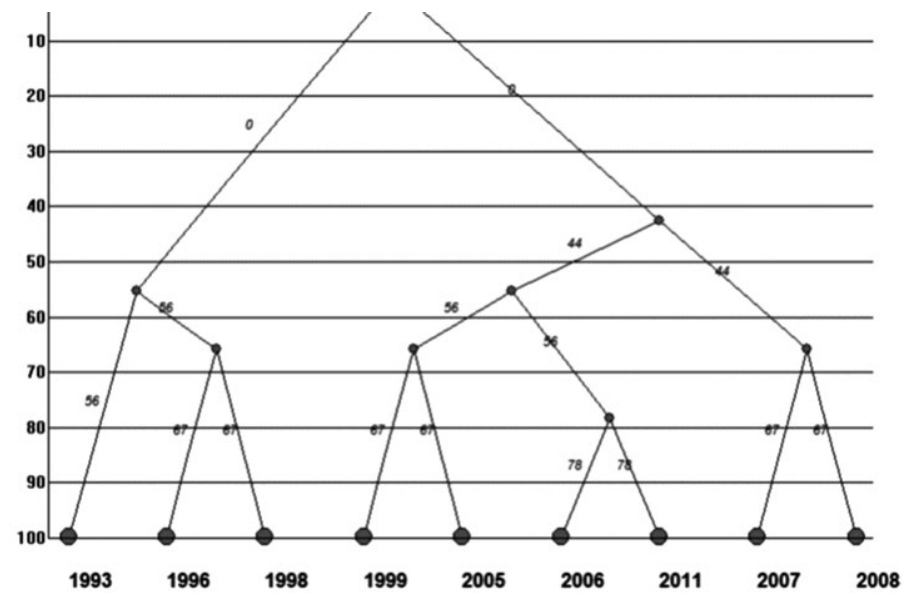

study period 1993-2011 showed that the value of total abundance and biomass of phytoplankton of the lake in the $1990 \mathrm{~s}$ was on average 1.5 times higher than in the years between 2000 and 2011 (Chekryzheva, 2012b). Their abundance in the 1990s averaged 766.0 thousand cells $\mathrm{L}^{-1}$ and from 2000-2011 reached to 490.0 thousand cells $\mathrm{L}^{-1}$. The phytoplankton biomass over the same period averaged 0.66 $\mathrm{g} \mathrm{cm}^{-3}$ and $0.44 \mathrm{~g} \mathrm{~cm}^{-3}$. However, the quantitative development of phytoplankton for the two periods was not so distinct at a significance level of 0.05 . Notably, the relative cell size reflects not only small-celled algal bloom periods but also the response of phytoplankton diversity to impact (Stolte, 1995; Negro et al., 2000; Alimov, 2001; Visljanskaya, 2007; Finkel et al., 2010; Zhang et al., 2012). Longterm dynamics of relative cell volume that we calculated for the entire study period (Fig. 4) shows that phytoplankton communities were enriched by small-celled species, such as Cyanobacteria (Microcystis aeruginosa, Dolichospermum lemmermannii), and cryptophytes (Cryptomonas sp. and Katablepharis ovalis), in the period between 1998 and 2006 when the total cell abundance and biomass were low (Tab. 3, Fig. 4a). Phytoplankton of this period contains a number of small-celled greens and Cryptophyta (Cryptomonas sp. and Katablepharis ovalis) as well as Cyanobacteria (Microcystis aeruginosa, Dolichospermum lemmermannii) (Tab. 3). In the same time, Shannon index of structural complexity is rather high (Tab. 3, Fig. 4b) and therefore reflect species rich communities that maintain a high level of stability under environmental impacts. Pearson correlation for Shannon and relative cell biovolume is negative -0.79 with $p$ value of 0.002 , which confirms that community was impacted during the blooms of small-celled algae as Microcystis aeruginosa. Remarkably, during two critical years, 1996 and 2007, a different relationship between the relative cell size and structural complexity was observed. As mentioned above (Tab. 3, Fig. 3), it was the

Fig. 7. Tree of similarity of the phytoplankton communities in the Kondopoga Bay of the Lake Onego calculated on the basis of Sørensen-Czekanowski indices. At the similarity level of $50 \%$ three clusters are cut off. 
time of large-celled Dinophyta bloom involving Ceratium hirundinella and Peridinium aciculiferum. Therefore, Dinophyta co-exist with the other plankters at low densities, but disrupt the structure of plankton communities at blooms. Causation of Dinophyta blooms in large lakes has not been given the attention it deserves, but a few examples (Zohary et al., 1998; Grigorszky et al., 2003) point to the blooms enhancing instability under increasing temperature and organic impacts. Even small northern lakes show high buffer capacity under industrial pollution impact (Blais et al., 1999), and for the large lakes as Onego the delay can be more significant. On the other hand, periods of dinoflagellate blooms $(1998,2007)$ are strongly followed by peaks of total abundance and biomass (1996, 2006).

We tried to relate the anthropogenic impacts to selfpurification capacities in the bay and extrapolate over the lake ecosystem as a whole. The saprobity indices reflect organic pollution that stimulate photosynthetic activity on the one hand, and species richness, on the other (Barinova, 2011), showing high self-purification capacities (Tab. 3). This conclusion is confirmed by WESI values which were more than 1.0 over the studied period, being relatively low in 1995 and 2007 (Fig. 5). It can be related to increases in nitrate and phosphate concentrations in these years, but with organic pollution (the Saprobity index S) concomitantly decreasing. To clarify the problem, we compare WESI with ecological information summarized in Tab. 3. While in critical years the Saprobity index S scarcely increased, the phosphate and nitrate concentrations levels are considerably elevated. This tendency can be seen in Fig. 5 during the last years (2007-2011) in respect to phosphates, which increased significantly. Therefore, the WESI conveys the increase in inorganic pollution during the last few years, at the same time attesting to self-purification capacities. Statistical analysis of species-environmental relationships with CCA (Fig. 6) of 18 abundant species and five most correlated chemical variables reveals increasing of abundance of the temperature and nitrogen indicators Anabaena scheremetievii, Dolichospermum lemmermannii, and Aulacoseira alpigena, as well as decreasing of sensitive to ammonia and Norg species Aulacoseira distans, Ankistrodesmus fusiformis, and Mucidosphaerium pulchellum.

We also analyzed regression coefficients for most significant pairs of variables. Our calculations shows significant positive relationships of species richness and Norg (0.697), and negative relationships of saprobity index S and water temperature (-0.667), ammonia (-0.694), and silica $(-0.725)$. In turn, the chemical variables are dependent each other as nitric nitrogen and temperature (0.707), or nitric nitrogen and Norg (-0.725), as well as iron and temperature (0.904). The comparative species richness analysis (Novakovsky, 2004) has divided phytoplankton into years representing three different clusters (Fig. 7), related to fluctuations in species diversity and nutrients. Species richness overlap analysis shows a high level of similarity of studied communities with similarity cores in 1996 and 2011. It looks like a very important change of environmental situations (years 1998 and 2011) in which the planktonic communities of the Kondopoga bay were formed. We speculate that turnover might have been related to a 100-fold increase of total nitrogen, which comes from the Kondopoga treatment plants to the Kondopoga bay after 1998 (Sabylina, 1999; Sabylina et al., 2010; Rukhovets and Filatov, 2010; Kalinkina et al., 2012).

On the other hand, the long-term study of the great lakes ecosystem (Petrova et al., 2010) revealed a multiparametric stressors impact (Summers et al., 2012), which can be inflicted not only by water pollution but also by the air dust (Psenner, 1999) and acidification (Skjelkvåle et al., 2005), but mostly related to anthropogenic load. In deep lakes of the humid zone such as the Lake Ladoga (Petrova et al., 2010) and Lake Superior (Pourriot and Meybeck, 1995), the ecosystem trends toward the allochthonous, heterotrophic type even notwithstanding the absence of significant increase in anthropogenic load (Petrova et al., 2010). In the case of the Onego Lake, the eutrophication trend is associated not only with the nutrients increase (Timakova et al., 2011) but also with multiparametric stressors, which in our bio-indication result are manifest in the rise of species with heterotrophic nutrition ability (Saks et al., 1976).

\section{CONCLUSIONS}

Our results suggest that the Kondopoga Bay ecosystem has high self-purification ability in spite of its anthropogenic impact from the Kondopoga pulp and paper mill wastewater. Bio-indication shows a trend of slight acidification and eutrophication of the bay waters. Our results characterize the Kondopoga Bay as similar to ecosystems of large lakes, such as the Lake Ladoga, under low year-round insolation as well as having the highest water temperatures in summer. The anthropogenic eutrophication process is localized in deep bays like the Kondopoga Bay. Its morphometric features and thermodynamics contribute to slowing down of the eutrophication process, at the same time spreading it over the entire area of the Lake Onego. Temperature and nutrients emerge from this study as the major factors of the lake ecosystem dynamics.

Future investigations of phytoplankton in this great northern lake would allow for more exact estimate of pollution intensity and the impact of the Kondopoga Bay eutrophication confers to the whole great lake ecosystem.

\section{ACKNOWLEDGMENTS}

This work has been partly funded by the Ministry of Absorption of Israel. 


\section{REFERENCES}

Alimov AF, 2001. [Elements of the theory of the functioning of aquatic ecosystems].[Book in Russian]. Nauka: 148 pp.

Anagnostidis K, Komárek J, 1988. Modern approach to the classification system of cyanophytes. 3. Oscillatoriales. Arch. Hydrobiol. Algological Studies 50/53:327-472.

Barinova S, 2011. Algal diversity dynamics, ecological assessment, and monitoring in the river ecosystems of the eastern Mediterranean. Nova Science Publishers, New York: 363 pp.

Barinova S, Sivaci R, 2013. Experimental approach to a lake ecosystem assessment in the Great Lota, Turkey. Experiment 9:566-586.

Barinova S, Tavassi M, Glassman H, Nevo E, 2010a. Algal indication of pollution in the Lower Jordan River, Israel. Appl. Ecol. Env. Res. 8:19-38.

Barinova SS, Krassilov VA, 2012. Algal diversity and bio-indication of water resources in Israel. Int. J. Environ. Res. 1:62-72.

Barinova SS, Medvedeva LA, Anissimova OV, 2006. [Diversity of algal indicators in environmental assessment]. [Book in Russian]. Pilies Studio: 498 pp.

Barinova SS, Tavassi M, Nevo E, 2010b. Algal communities of the Hadera River (Israel) under dramatic niche change. Centr. Eur. J. Biol. 5:507-521.

Belous EP, Lilitzkaya GG, Krivenda AA, 2013. Seasonal fluctuation of phytoplankton in the upper part of the Southern Bug River (Ukraine). Algologia 1:53-64.

Blais JM, Duff KE, Laing TE, Smol JP, 1999. Regional contamination in lakes from the Noril'sk region in Siberia, Russia. Water Air Soil Pollut. 110:389-404.

Blomqvist P, Peterson A, Hyenstrand P, 1994. Ammonium nitrogen: A key regulatory factor causing dominance of nonnitrogen-fixing cyanobacteria in aquatic systems. Arch. Hydrobiol. 132:141-164.

Boyarinov PM, Rudnev SF, 1990. [Instrumental methods of research trends], p. 53-71. In: Z.S. Kaufman (ed.), [The ecosystem of the Onego Lake and the trends of its changes].[Book in Russian]. Nauka, Leningrad.

Carlson RE, Simpson J, 1996. A coordinator's guide to volunteer lake monitoring methods. North American Lake Management Society: $96 \mathrm{pp}$.

Chekryzheva TA, 2008a. [Changes in the structure of summer phytoplankton in the Kondopozhskaya Bay of the Lake Onego in the process of anthropogenic eutrophication], p. 156-163. Proceedings Karelian Research Centre of Russian Academy of Sciences, Issue 12. Ser. Biogeography. [Article in Russian]. Karelian Research Centre of Russian Academy of Sciences, Petrozavodsk.

Chekryzheva TA, 2008b. [Phytoplankton as a component of the base of the lake bioresource. Biological resources of the Lake Onego], p. 24-35.[Article in Russian]. Karelian Research Centre of Russian Academy of Sciences, Petrozavodsk.

Chekryzheva TA, 2012a. [Long-term changes in the structure of the phytoplankton biomass of the Lake Onego. Ecological problems of the northern regions and their solutions], p. 250255. [Article in Russian]. Proceedings IV Scientific Conference Kola Scientific Centre RAS. Institute of North Industrial Ecology Problems, Apatity.

Chekryzheva TA, 2012b. [Taxonomic and ecological characteristics of phytoplankton in Lake Onego], p. 56-69. Proceedings Karelian Research Centre of Russian Academy of
Sciences. Issue 13. Ser. Biogeography. [Article in Russian]. Karelian Research Centre of Russian Academy of Sciences, Petrozavodsk.

Dedusenko-Schegoleva NT, Hollerbach MM, 1962. [Yellowgreen algae].[Book in Russian]. USSR Academy of Sciences: 272 pp.

Dedusenko-Schegoleva NT, Matvienko A, Shkorbatov LA, 1959. [Green algae].[Book in Russian]. USSR Academy of Sciences: $230 \mathrm{pp}$.

European Commission, 2000. Parliament and Council decision of 23 October 2000 establishing a framework for Community action in the field of water policy, 2000/60/EC. In: Official Journal, L 327, 22/12/2000, p. 1-73.

Fedorov VD, 1979. [On methods of studying phytoplankton and its activity].[Book in Russian]. Moscow State University: $166 \mathrm{pp}$.

Filatov NN, 2010. [The Lake Onego. Atlas].[Book in Russian]. Karelian Research Centre of Russian Academy of Sciences: $151 \mathrm{pp}$.

Finkel ZV, Beardall J, Flynn KJ, Quigg A, Alwyn V, Rees TV, Raven JA, 2010. Phytoplankton in a changing world: cell size and elemental stoichiometry. J. Plankton Res. 32:119-137.

Genkal SI, Trifonova IS, 2009. [Diatoms in the plankton of the Ladoga Lake and waterbodies of its basin].[Book in Russian]. Rybinsk Printing House: 72 pp.

George G, 2010. The impact of climate change on European lakes. 1st edn. Springer, Berlin: 507 pp.

Grigorszky I, Borics G, Padisak J, Totmeresz B, Vasas G, Nagy S, Borbely G, 2003. Factors controlling the occurrence of Dinophyta species in Hungary. Hydrobiologia 506:203-207.

Havens KE, Phlips EJ, Cichra MF, Li B-L, 1998. Light availability as a possible regulator of cyanobacteria species composition in a shallow subtropical lake. Freshwater Biol. 39:547-556.

Heywood V, 2004. Modern approaches to floristics and their impact on the region of SW Asia. Turk. J. Bot. 28:7-16.

Hollerbach MM, Kosinskaya EK, Polanski VI, 1953. [Bluegreen algae].[Book in Russian]. Soviet Science: 652 pp.

Hustedt F, 1938-1939. [Systematisch und Oekologische Untersuchungen ueber die Diatomeen-Flora von Java, Bali und Sumatra, nach dem Material der Deutschen Limnologischen Sunda-Expedition: Allgemeiner Teil].[Book in German]. E. Schweizerbart'sche Verlagsbuchhandlung (E. Nägele). 709 pp.

Hustedt F, 1958. [Diatomeen aus der Antarktis und dem Südatlantik. Deutsche Antarktische Expedition 1938/1939].[Article in German]. Geographisch-kartographische Anstalt Mundus 2:103-191.

Jeppesen E, Kronvang B, Meerhoff M, Sondergaard M, Hansen KM, Andersen HE, Lauridsen TL, Liboriussen L, Beklioglu M, Ozen A, Olesen JE, 2009. Climate change effects on runoff, catchment phosphorus loading and lake ecological state, and potential adaptations. J. Envir. Qual. 38:1930-1941.

Kalinkina NM, Kulikova TP, Litvinova IA, Polyakova TN, Syarki MT, Tekanova EV, Timakova TM, Chekryzheva TA, 2012. Indication of Water and Bottom Sediment Pollution in the Kondopozhskaya Bay of Lake Onego. Water Resour. 39:776-783.

Kukharev VI, Lukin AA, 2008. [Bioresources of the Lake Onego].[Book in Russian]. Karelian Research Centre of Russian Academy of Sciences: 272 pp. 
Kiselev IA, 1954. [Pyrrophyta algae].[Book in Russian]. Soviet Science: $212 \mathrm{pp}$.

Komárek J, Anagnostidis K, 1986. Modern approach to the classification system of cyanophytes. 2. Chlorococcales. Arch. Hydrobiol. 73:157-226.

Korshikov OA, 1953. [Handbook of freshwater algae of Ukrainian SSR].[Book in Russian]. USSR Academy of Sciences $439 \mathrm{pp}$.

Kosinskaya EK, 1960. [Flora of spore-bearing plants in the USSR].[Book in Russian]. USSR Academy of Sciences: 704 pp.

Krammer K, Lange-Bertalot H, 1986. [Bacillariophyceae. 1. Naviculaceae], p. 1-876. In: H. Ettl, J. Gerloff, H. Heying and D. Mollenhauer (eds.), [Süsswasserflora von Mitteleuropa].[Book in German]. Fischer.

Krammer K, Lange-Bertalot H, 1988. [Bacillariophyceae. 2. Bacillariaceae, Epithemiaceae, Surirellaceae], p. 1-596. In: H. Ettl, J. Gerloff, H. Heying and D. Mollenhauer (eds.), [Süsswasserflora von Mitteleuropa].[Book in German]. Fischer.

Krammer K, Lange-Bertalot H, 1991. [Bacillariophyceae. 3. Centrales, Fragilariaceae, Eunotiaceae], p. 1-576. In: H. Ettl, J. Gerloff, H. Heying and D. Mollenhauer (eds.), [Süsswasserflora von Mitteleuropa].[Book in German]. Fischer.

Matvienko AM, 1954. [Freshwater algae of the USSR. Golden algae].[Book in Russian]. Soviet Science: 188 pp.

Matvienko AM, Litvinenko RM, 1977. [Pyrrophyta algae].[Book in Russian]. Nauka: 386 pp.

Ministry of the Environment and Statistics, 2010. Finland's First National Communication under the United Nations Framework Conventions on climate change. Ministry of the Environment and Statistics Finland: 282 pp.

Morduhay-Boltovskiy FD, 1975. [Method of study biogeocenosis of inland waters].[Book in Russian]. Nauka: $250 \mathrm{pp}$.

Nazarova LE, 2012. Features of the dynamics of the temperature regime of Karelia. Geogr. Nat. Res. 4:170-174.

Negro AI, De Hoyos C, Vega JC, 2000. Phytoplankton structure and dynamics in Lake Sanabria and Valparaíso reservoir (NW Spain). Hydrobiologia 424:25-37.

Novakovsky AB, 2004. [Abilities and base principles of program module GRAPHS].[Article in Russian]. Scientific reports of Komi Scientific Centre. Ural Division of the Russian Academy of Sciences 27:1-28.

Odum EP, 1969. The strategy of ecosystem development. Science 164:262-270.

Olrik K, 1998. Ecology of mixotrophic flagellates with special reference to Chrysophyceae in Danish lakes. Hydrobiologia 369/370:329-338.

Palamar-Mordvintseva GM, 1982. [Desmid algae of Ukrainian SSR].[Book in Russian]. Naukova Dumka: 619 pp.

Petrova NA, Petrova TN, Susareva OM, Iofina IV, 2010. Features of evolution the Lake Ladoga ecosystem due to anthropogenic eutrophication. Water Resour. 37:580-589.

Petrova NA, 1968. [Phytoplankton of the Ladoga Lake], p. 73130. In: S.V. Kalesnik and I.M. Raspopov (eds.), [Plant resources of the Ladoga Lake].[Book in Russian]. Leningrad Univ. Press.

Petrova NA, 1971. [Phytoplankton of the Onego Lake], p. 88127. In: I.M. Raspopov (ed.), [Plant resources of the Onego Lake].[Book in Russian]. Nauka.

Petrova NA, 1975. [Phytoplankton of the littoral zone of the
Onego Lake], p. 138-144. In: I.M. Raspopov (ed.), [Littoral zone of the Onego Lake].[Book in Russian]. Nauka.

Petrova NA, 1986. Seasonality of Melosira - plankton of the great northern lakes. Hydrobiologia 138:65-73.

Petrova NA, 1990. [Succession of phytoplankton under anthropogenic eutrophication of large lakes].[Book in Russian]. Nauka: 200 pp.

Pourriot R, Meybeck M, 1995. [Limnologie generale].[Book in French]. Masson: $956 \mathrm{pp}$.

Popova TG, 1955. [Euglenophyta (Euglenophyta) - Key to freshwater algae of the USSR].[Book in Russian]. Soviet Science: $282 \mathrm{pp}$.

Psenner R, 1999. Living in a dusty world: airborne dust as a key factor for alpine lakes. Water Air Soil Poll. 112:217-227.

Pugnetti A, Acri F, Alberighi L, Barletta D, Bastianini M, Bernardi-Aubry F, Berton A, Bianchi F, Socal G, Totti C, 2004. Phytoplankton photosynthetic activity and growth rates in the NW Adriatic Sea. Chem. Ecol. 20:399-409.

Romanenko VD, Oksijuk OP, Zhukinsky VN, Stolberg FV, Lavrik VI, 1990.[Ecological impact assessment of hydrotechnical constructions on water bodies].[Book in Russian]. Naukova Dumka: 256 pp.

Rukhovets L, Filatov N, 2010. Ladoga and Onego - Great European lakes: observation and modeling. Springer-Praxis: 320 pp.

Rücker J, Wiedner C, Zippel P, 1997. Factors controlling the dominance of Planktothrix agardhii and Limnothrix redekei in eutrophic shallow lakes. Hydrobiologia 342/343:107-115.

Sabylina AV, 1999. [Modern hydrochemical regime of the lake], p. 58-108. In: N.N. Filatov (ed.), [The Lake Onego. Ecological problems].[Book in Russian]. Karelian Research Centre of Russian Academy of Sciences.

Sabylina AV, Ryzhakov AV, 2007. [The Onego Lake and its tributaries. The chemical composition of the water of the lake], p. 29-40. In: P.A. Lozovik, T.P. Kulikova, N.N. Martynova (eds.), [Status of water objects in Republic of Karelia. According to 1998-2006 monitoring results].[Book in Russian]. Karelian Research Centre of Russian Academy of Sciences.

Sabylina AV, Lozovik PA, Zobkov MB, 2010. The chemical composition of the water of the Lake Onego and its tributaries. Water Resour. 37:717-729.

Sabylina AV, Efremova TA, Ryzhakov AV, Zobkov MB, 2012. [Biogenic elements and organic matter in the Lake Onego and its bays], p. 75-79. In: P.A. Lozovik (ed.), [Organic matter and nutrients in inland waters and marine waters].[Book in Russian]. Karelian Research Centre of Russian Academy of Sciences.

Saks NN, Stone RJ, Lee JJ, 1976. Autotrophic and heterotrophic nutritional budget of salt marsh epiphytic algae. J. Phycol. 12:443-448.

Skjelkvåle BL, Stoddard JL, Jeffries DS, Tørseth K, Høgåsen T, Bowman J, Mannio J, Monteith DT, Mosello R, Rogora M, Rzychon D, Vesely J, Wieting J, Wilander A, Worsztynowicz A, 2005. Regional scale evidence for improvements in surface water chemistry 1990-2001. Environ. Poll. 137:165-176.

Sládeček V, 1973. System of water quality from the biological point of view. Adv. Limnol. 7:1-28.

Sládeček V, 1986. Diatoms as indicators of organic pollution. Acta Hydroch. Hydrob. 14:555-566.

Starmach K, 1985. [Chrysophyceae und Haptophyceae], p. 1- 
594. In: H. Ettl, J. Gerloff, H. Heynig and D. Mollenhauer (ed.), [Süsswasserflora von Mitteleuropa, Band 1].[Book in German]. Gustav Fischer Verlag.

Stewart AJ, Wetzel RG, 1986. Cryptophytes and other microflagellates as couplers in planktonic community dynamics. Arch. Hydrobiol. 106:1-19.

Stolte W, Riegman R, 1995. Effect of phytoplankton cell size on transientstate nitrate and ammonium uptake kinetics. Microbiology 141:1221-1229.

Summers JC, Ruhland KM, Kurek J, Quinlan R, Peterson AM, Smol JP, 2012. Multiple stressor effects on water quality in Poplar Bay, Lake of the Woods, Canada: a midge-based assessment of hypolimnetic oxygen conditions over the last two centuries. J. Limnol. 71:34-44.

Ter Braak CJF, Šmilauer P, 2002. CANOCO Reference Manual and CanoDraw for Windows User's Guide: Software for canonical community ordination, ver. 4.5. Microcomputer Power Press: 500 pp.

Ter Braak CJF, 1987. The analysis of vegetation-environment relationships by canonical correspondence analysis. Vegetatio 69:69-77.

Ter Braak CJF, 1990. Interpreting canonical correlation analysis through biplots of structural correlations and weights. Psychometrica 55:519-531.

Timakova TM, Sabylina AV, Polyakova, TP, Syarki MT, Tekanova EV, Chekryzheva TA, 2011. [The current state of the ecosystem of the Lake Onego and the tendencies of its changes over the past decades], p. 42-49. In: Proceedings Karelian Research Centre of Russian Academy of Sciences. [Article in Russian]. Karelian Research Centre of Russian Academy of Sciences.
Trifonova IS, 1990. [Ecology and succession of the lake phytoplankton].[Book in Russian]. Nauka: 184 pp.

Van Dam H, Mertens A, Sinkeldam J, 1994. A coded checklist and ecological indicator values of freshwater diatoms from The Netherlands. Neth. J. Aquat. Ecol. 28: 17-133.

Vislyanskaya IG, 1990. [Phytoplankton], p. 183-192. In: Z.S. Kaufman (ed.), [The ecosystem of the Lake Onego and trends of its change]. [Book in Russian]. Nauka.

Vislyanskaya IG, 1999. [Structure and dynamics of phytoplankton biomass], p. 146-158. In: N.N. Filatov (ed.), [The Lake Onego. Environmental problems]. [Book in Russian]. Karelian Research Centre of Russian Akademy of Sciences.

Vislyanskaya IG, 2007. [Phytoplankton], p. 49-54. In: P.A. Lozovik, T.P. Kulikova, N.N. Martynova (eds.), [Status of water objects in Republic of Karelia. According to 19982006 monitoring results].[Book in Russian]. Karelian Research Centre of Russian Academy of Sciences.

Whitton BA, Rott E, Friedrich G, 1991. Use of algae for monitoring rivers. Institut für Botanik, Innsbruck University Press: 193 pp.

Zabelina MN, Kiselev IA, Proshkina-Lavrenko AI, Sheshukova VS, 1951. [Diatoms]. [Book in Russian]. Soviet Science: $619 \mathrm{pp}$.

Zhang Y, Yin Y, Wang M, Liu X, 2012. Effect of phytoplankton community composition and cell size on absorption properties in eutrophic shallow lakes: field and experimental evidence. Opt. Express 20:11882-11898.

Zohary T, Pollingher U, Hadas O, Hambright KD, 1998. Bloom dynamics and sedimentation of Peridinium gatunense in Lake Kinneret. Limnol. Oceanogr. 43:175-186. 